Magdy Ahmed Abdelhameed

\title{
A Linguistic and Cognitive Analysis of Selected Metaphors in The Holy Qur'an
}

\author{
A paper presented by \\ Magdy Ahmed Abdelhameed
}

List of Arabic Phonetic symbols

(IPA)

Consonants

\begin{tabular}{|c|c|c|}
\hline Arabic & Description & Transcription \\
\hline i & Voice glottal stop & $?$ \\
\hline ب & Voiced bilabial stop & $\mathrm{b}$ \\
\hline$ت$ & Voiceless dento-alveolar stop & $\mathrm{t}$ \\
\hline$\dot{H}$ & Voiceless interdental fricative & $\theta \nsubseteq$ \\
\hline ج & Voiced post-alveolar fricative & $j^{*}$ \\
\hline$\tau$ & Devoiced pharyngeal fricative & $\hbar$ \\
\hline$\dot{\tau}$ & Voiceless velar fricative & $\dot{\mathrm{x}}$ \\
\hline د & Voiced dento-alveolar & $\mathrm{d}$ \\
\hline$\dot{j}$ & Voiced interdental frivative & $\underline{\mathrm{d}}$ \\
\hline J & Voiced alveo-palatal trill & $\mathrm{r}$ \\
\hline j & Voiced alveolar fricative & $\mathrm{z}$ \\
\hline س & Voiceless alveolar fricative & $\mathrm{S}$ \\
\hline ش & Voiceless alveopalatal fricatives & $\check{\mathrm{s}}$ \\
\hline ص & Voiceless velarized alveolar fricative & $\mathrm{S}^{*}$ \\
\hline 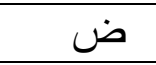 & Voiced velarized dento-alveolar stop & $Đ$ \\
\hline b & $\begin{array}{l}\text { Voiceless velarized dento-alveolar } \\
\text { stop }\end{array}$ & $\mathrm{t}$ \\
\hline ظ & Voiced velarized interdental fricative & $\mathrm{Z}^{*}$ \\
\hline$\varepsilon$ & Voiced pharyngeal fricative & ؟ \\
\hline$\dot{\varepsilon}$ & Voiced uvular stop & $\varsigma^{*}$ \\
\hline ف & Voiceless labio-dental fricative & $\mathrm{f}$ \\
\hline ق & Voiceless uvular stop & $\mathrm{q}$ \\
\hline 5 & Voiceless velar stop & $\mathrm{k}$ \\
\hline J & Voiced alveolar lateral & 1 \\
\hline 5 & Voiced bilabial nasal & $\mathrm{m}$ \\
\hline ن & Voiced alveolar nasal & $\mathrm{n}$ \\
\hline 0 & Voiceless glottal fricative & $\mathrm{h}$ \\
\hline 9 & Voiced labiovelar glide & $\mathrm{W}$ \\
\hline s & Voiced palatal glide & $\mathrm{y}$ \\
\hline
\end{tabular}


A Linguistic and Cognitive Analysis of Selected Metaphors in The Holy Qur'an

Vowel endings and long vowels

\begin{tabular}{|c|l|c|}
\hline Symbol & \multicolumn{1}{|c|}{ Description } & example \\
\hline $\mathrm{e}$ & Front short close vowels & /xaaleq/ creator \\
\hline $\mathrm{a}$ & Front short open vowel & /baaSa/ sold \\
\hline $\mathrm{u}$ & Back short close vowel & /muhaarib/ warrior \\
\hline $\mathrm{aa}$ & Front long open vowel & / $\mathrm{haad} /$ sharp \\
\hline $\mathrm{uu}$ & Back long close vowel & /turuud/ parcels \\
\hline
\end{tabular}

\section{Abstract}

This study examines the orientational metaphors in the Holy Qur'an which contribute to the cardinal Qur'anic theme of peace, based on the conceptual metaphor framework developed by George Lakoff and Mark Johnson (1980), and the Pragglejaz model of Metaphor Identification (2010). This paper will focus on orientational metaphors.

\section{Key Words}

\section{The Holy Qur'an CMT MIPVU Orientational metaphor Pragglejazz Mappings peace}

\section{Introduction}

Conceptual Metaphor Theory as proclaimed by Lakoff and Johnson in their seminal work Metaphor We Live By (1980), changed the locus of attention regarding metaphor from language to "thought". Metaphor became no longer a violation of lexical and semantic rules, but a mental process where mapping occurs between the salient characteristics of two domains. The Target Domain (TD) is an abstract domain defined via mapping the salient properties of a Source Domain onto it.

The study highlights "peace" as one of the major themes in the Holy Qur'an recognized as a "heavily didactic book" (Chartaris-Black 2004, p. 221). The Holy Qur'an is concerned with establishing "peace" in the world, psychologically, domestically and socially. This paper is limited to inner psychological peace and attempts to highlight how the Holy Qur'an educates the believers to find peace within and realize it in the world around them. This is accomplished by conceptualizing the life of a Muslim as a journey along a PATH towards a GOAL. On that path, the use of orientational metaphors is the most suitable for the description of the journey, since it involves travelling near to or far from clearly defined objects. It also involves UP-lifting certain concepts and putting DOWN others. 


\section{Magdy Ahmed Abdelhameed}

Therefore, the study is an attempt to present answers to the following queries:

1-Based on Conceptual Metaphor Theory (Henceforth CMT) as in Lakoff and Johnson (1980), how does the Holy Qur'an use orientational conceptualization to help a Muslim establish inner peace?

2- Can the Pragglejaz tool for Metaphor Identification Process (Henceforth MIPVU) be applied in the analysis of an Arabic text?

\section{Theoretical Framework}

\subsection{Conceptual Metaphor Theory}

\subsubsection{Orientational Metaphor}

The defining feature of Orientational metaphor is the use of the basic human spatial orientations mapped onto non-spatial objects. Orientational metaphors can, for instance, map a spatial or sensori-motor image-schema onto an abstract domain. An example is 'My spirits sank' in which sadness is conveyed through the concept of a downward movement. The concept of quantity, for example, involves at least two metaphors: UP and DOWN. Prices plummeted, or soared; 'Our relationship went downhill': SADNESS IS DOWN; 'We are on cloud nine' HAPPINESS IS UP; down in the dumps, etc. Moving FORWARD or BACKWARD; BEYOND, and AHEAD OF present metaphorical expression as a solution to the abstract linear scales and paths schemas. In "the progress of Japan goes AHEAD OF China's", ahead of is from the spatial domain showing direction and linear scales. From another perspective, the appreciation of upward positions can be attributed to the traditional belief that Heaven, with its pleasures, exists somewhere in the sky. On the other hand, the appreciation of the DOWN metaphor can be attributed to its association with the ideas: 'ground', 'earth', and 'dirt'. One can also postulate that it is attributed to the concept of 'Hell' that is conventionally represented located in a lower place, as in the "under-world".

Embodiment is an intrinsic component in language, and in metaphorical discourse in particular. The representation of abstract concepts in the mind is grounded in our physical experience of the world. The body plays a significant role in shaping our thought; this is why many metaphors involve embodiment (Turner, 1996, pp. 16-18). Mapping is rooted in embodied experience.

"Culture, body and mind are inseparable' (Gibbs, 1999: p. 146). Embodied experience is correlated with cultural background (Kövecses, 2006, p. 203). The study of metaphor is "cultural-cognitive". Culture is seen as mental representations structured by cultural models and frames (Shore 1996; Quinn 1997; Kövecses 2005). "What is conceptual about metaphor involves the significant aspects of cultural experience, some of which is even intimately related to our embodied behaviours" (Gibbs, 
1999, p. 146). Allan (2008) even asserts that conceptual metaphors can be interpreted only by considering the cultural context in which they occur.

\subsection{MIPVU}

The MIPVU tool marks Metaphor Related Words (hence, MRWs) by contrasting the basic meaning of lexical units against their contextual meaning of potentially metaphorical words. In response to the need for a systematic method for identifying instances of metaphor use conforming to the new definition, the Pragglejaz Group at VU University, Amsterdam, collaborated for six years (Steen, 2010, p. 166). MIPVU (2007) gives precise instructions for finding Metaphor-Related Words (MRWs) following the basic guidelines below adapted from Steen et al. (2010, p. 25-26):

1. Divide the text into lexical units.

2. Mark the lexical unit as metaphorical (MRW) if its contextual use may be explained via cross-domain mapping as different from its basic meaning.

3. Mark a lexical unit (MRW, direct) when mapping is instigated through analogy or similarity.

4. Mark a lexical unit as (MRW, implicit) in case of pronominal substitution, or ellipsis of certain lexical items as a form of coordination.

5. Metaphor signals are marked Metaphor Flags (MFlag).

\section{Review of Related Literature}

The application of orienational metaphor analysis has been rather limited compared with the other types of schematic metaphor; since "orientational metaphors are based in relatively lower-level mappings" (Kaal 2012, p. 23).

Soskice (1985) employed the theories of Richards and Black to develop the most influential account of metaphor and religious language to appear to date. She regards the function of a metaphor in religious context as primarily cognitive as well as explanatory. Soskice draws attention to the metaphorical reference to God in all three religions, concluding that such metaphorical attempts are complementary, maybe overlapping, but not contradictory. Jonathan Chartaris-Black's Corpus Approaches to Critical Metaphor Analysis (2004), which presents corpus analysis of Al-Torah, Al-Injeel, and Al-Qur'an in addition to half a dozen corpus analyses of different genres of discourse. Black conducts analysis of conceptual metaphors of LIGHT, FIRE, and WEATHER in the "Koran" as he calls it.

Ahamed Al-Sherif (2011) examines the emergence of metaphorical language in tradition of Prophet Muhammad. It principally 


\section{Magdy Ahmed Abdelhameed}

argues that the selection of metaphors in the Prophetic discourse is chiefly governed by the rhetorical aim of persuasion. Additionally, the Prophetic metaphors are discursively used to express a distinctive Islamic doctrine and ideology that embody the laws, principles, and beliefs of Islam.

Mostapha Thabit (2014) investigates the metaphors of natural phenomena in the Holy Quran. He names five major metaphors: rain, mountain, wind, light, and darkness, conducting his analysis within the framework of Chartaris Black's theory of Critical Discourse Analysis. The study validates the adequacy of the application of CMA in the analysis of metaphors of natural phenomena in the Holy Quran

\section{Methodology and Procedure}

\subsection{Data Collection}

The selected verses are potentially metaphorical and serve the purpose of the paper; that is, to prove that the Holy Qur'an is a book that calls for peace in theory and practice. The paper proclaims that the Holy Qur'an introduces three levels of peace: inner, domestic and social. The selected Ayahs are not intended to present, but to represent, all the didactic ones. Al-Qur'an-ol-Kareem contains thousands of Ayahs, and from a different angle, it can be argued that literally every Ayah is a didactic one, in a way.

\subsection{Methodology}

The Ayahs of the Holy Qur'an are thematically labelled. Then, the potentially metaphorical words are classified as lexical units. The metaphoricity of the lexical units is verified by using MIPVU process. Arabic-Arabic dictionaries are consulted to explore gaps between the basic and contextual meanings.

It follows that the interpretation and function of the metaphorical structure are highlighted and integrated into the mainstream discussion as seen within the theme of "peace" in the Glorious Qur'an.

\section{The Analysis}

\subsection{Orientational metaphors and inner peace}

AL-TAQWA (PIETY) IS UP is one of the prominent orientational metaphors in the Holy Qur'an. First, Al-Taqwa is an attribute of the faithful, who give money to the needy, fulfill their promises and treaties, and are patient and honest (Al-Baqara 2:177).

Being a fundamental concept in the Holy Qur'an, "Al-Taqwa" is conceptualized in many ways extending its meaning from the abstract to spatial or locative in more than one situation. In the next two examples "al-taqwa" is target for the believer and a Target Domain for the researcher. The Holy Qur'an uses polarity to instruct the believers as to what they should HEAD towards or BACK OFF from to get closer to 
PIETY. It looks like a visual PATH for the believers to START the journey along to get to make it to that GOAL.

Two items on the way to the destination are "justice" and "forgiveness" as parts of spatial metaphors. The two orientational metaphors are grounded in sensorimotor perception mapped onto the abstract domain of Al-Taqwa. Moving NEARER to Al-Taqwa is a twofold achievement since it implies moving AWAY from evil. NEARER is a cohesive factor between "justice" and "forgiveness" on the one hand, and "Al-Taqwa on the other:

\begin{tabular}{|c|c|}
\hline 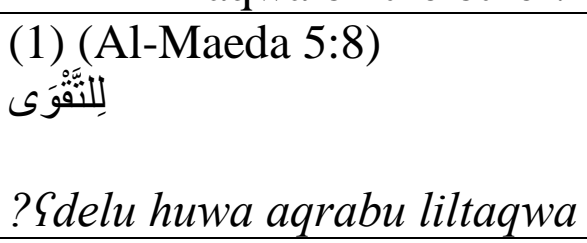 & اعْدِلْوَ اهُوَ أَقرَبُبُ \\
\hline Be just: that is next to piety & (Ali) \\
\hline
\end{tabular}

and "الـعَفَوَو/alSafw/ forgiveness" (11.a):

(2) (Al-Baqarah 2: 237)

Wa-an tasfu aqrabu liltaqwa

and the remission (of the man's half) is the nearest to righteousness. (Ali)

In the same vein, Al-Qur'an-ol-Kareem teaches Musslims that they ought to move AWAY from some of their daily social habits which include getting intoxicated, gambling, etc., and slams all as "part of the evil work of the Devil". It is amazing that the pronominal reference attached to the instructional verb is "Ijtanibooh" meaning shun, is it, not THEM. The shift from reference to abovementioned concrete items to the abstract "the devil's work", implies deliberateness to use metaphorical expression, the conceptual type:

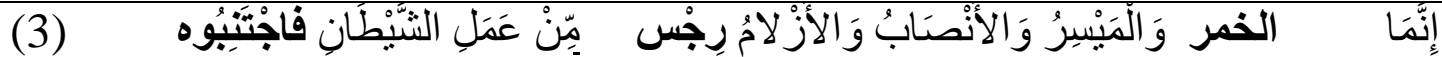
(Al-Maeda 5:90)

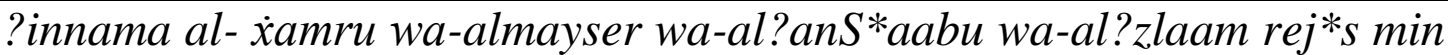
Samal al-shytaan fa-?ij*tanebuuh

O ye who believe! Intoxicants and gambling, (dedication of) stones, and (divination by) arrows, are an abomination,- of Satan's handwork: eschew such (abomination)

(Ali) 


\section{Magdy Ahmed Abdelhameed}

The physical sensorimotor "ij*tanebuuh" implies body movement AWAY from the abstract "Camali alšaytani", to which the pronominal "h" in "ij*tanebuuh" refers.

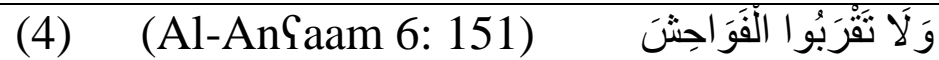

Wa-la taqrabu al-fawaheša

come not nigh to shameful deeds

(Ali)

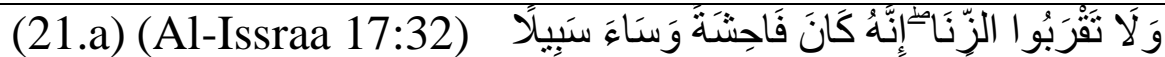

Wa-la taqrabu al-zina ?nnahu kan fahišatan wa-saa sabeela

Nor come nigh to adultery: for it is a shameful (deed) and an evil, opening the road (to other evils).

(Ali)

\begin{tabular}{|l|}
\hline (22) (Al-Hajj 22:30) \\
Wa-ijtanibu qawl alzuur \\
\hline but shun the abomination of idols, and shun the word that is false, (Ali) \\
\hline
\end{tabular}

\begin{tabular}{|c|c|}
\hline The lexical unit & nouns \\
\hline \multirow{6}{*}{ 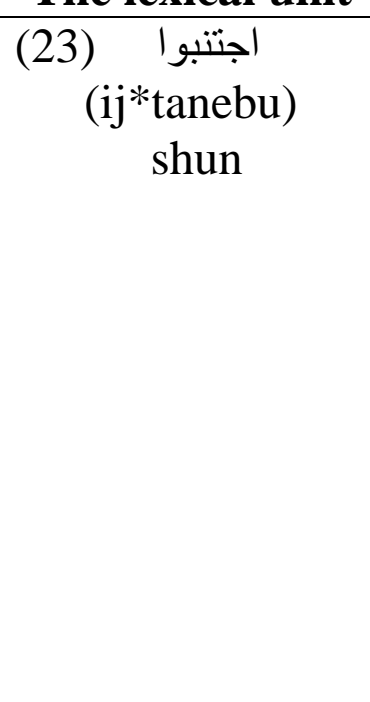 } & 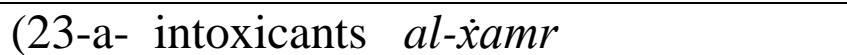 \\
\hline & 23-b games of chance al-maysir الميسر \\
\hline & 23-c stones al-?ans*aab) الأنصاب \\
\hline & $\begin{array}{l}\text { 23-d arrows (fortune-telling) al-?azlaam } \\
\text { الأزلام }\end{array}$ \\
\hline & 23-e qawl alzuur \\
\hline & 23-f $\quad$ suspicion $a l-Z * a n$ \\
\hline \multirow{2}{*}{$\begin{array}{l}(23-23 . a) \quad \text { تقربوا } \\
\text { La-taqrabu } \\
\quad \text { go not near }\end{array}$} & 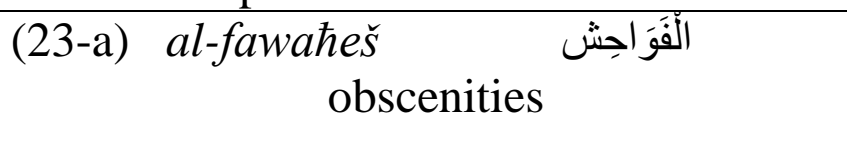 \\
\hline & (23-b) adultery al-zina \\
\hline
\end{tabular}


A Muslim's goal is, and should always be, PEACE. Once the transgressors have opted for peace, Muslims are ordered to move equally in the same direction and the same pace:

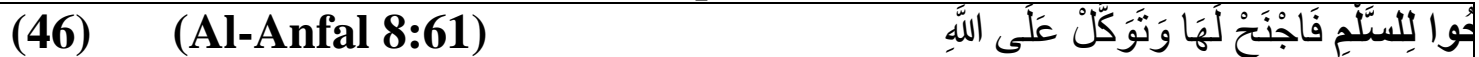

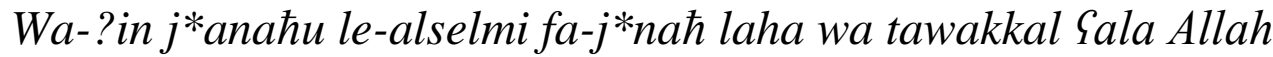

But if the enemy incline towards peace, do thou (also) incline towards peace, and trust in Allah (Ali)

I $/ j * a n a \hbar u /$ consists of two lexical units "they" - transgressors - and the verb form derived from the wing of a bird, similar to "side towards". The "wing" image is an element of embodiment. According to Lakoff and Johnson:

"The concepts front and back are body-based. They make sense only for beings with fronts and backs...We have faces and move in the direction in which we see. Our bodies define a set of fundamental spatial orientations that we use not only in orienting ourselves, but in perceiving the relationship of one object to another (Philosophy in the Flesh, 1999, p. 35)

لَهَllaha/: to it" is a metaphor by substitution according to MIPVU; "ha/ it" is a pronoun-suffix referring to peace. Muslim scholars (Al-Qurtuby, Ibn-Katheer, etc.), interpret " السلل /al-salm/" as "peace", which is a masculine noun. However, " Lَه/ha/" meaning "it" refers to a female entity. Now, there is an apparent conflict between the masculine "peace" and the anaphoric "it". Yet, it is most likely that Al-Qur'an-ul Kareem used ellipsis in this context. The ellipsis of "

The verses envisage a virtual JOURNEY on the STRAIGHT PATH to the GOAL every believer should perceive as their DESTINATION. On the side(s) of the PATH there are traps where "Al- šaytan" awaits those with weak faith to follow his steps:

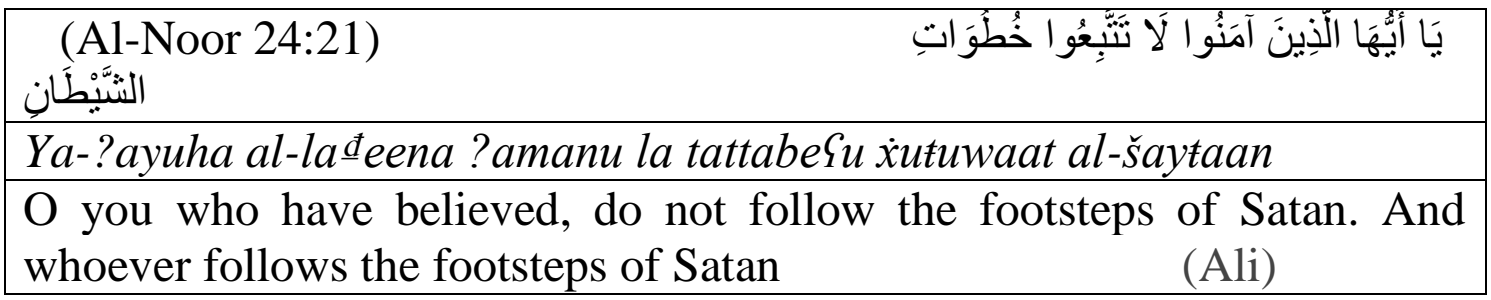

Allah exclusively addresses the believers with "O you who believe". This, scholars emphasize, heightens the sense of belonging, 


\section{Magdy Ahmed Abdelhameed}

closeness and the concept of divine care. The basic meaning of "rij*sun" is rotten dirt that must be removed from wells before raising water from them. However, the use of "rij*sun" as a source domain is more powerfully effective when attributed to the work of the devil. Drinking and gambling were essential practices in pre-Islamic time. Giving the image this diabolic dimension augments and activates the mapping process in coherence with the immediately following order: "ij*tanibuuh", or "shun it". Therefore, "rij*sun min Samal al-šaytaan" strikes the Musslims' understanding as one unit, wherever the word "rij*s" occurs in the Holy Book.

PIETY IS UP

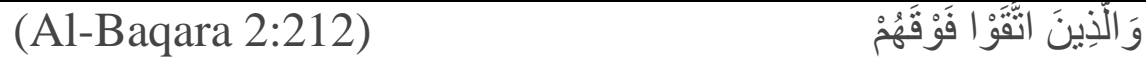

Wa-?alla đeen ?ittaqaw fawqahum

But the righteous will be above them

(Ali)

The exalted value of at-taqwa as a concept is metaphorically assured. "Piety" is an elevated entity, and constitutes a rank that should be coveted by all, especially Muslims. The word "above" is perceived literally and metaphorically. The metaphorical connotation is bound to this world, where the "pious" should feel rewarded for their goodness words and actions.

\subsection{MIPVU}

\section{GOOD WORDS AND ACTIONS ARE UP}

MIPVU identifies metaphor related words (MRWs) by comparing the basic dictionary use of certain words with their contextual meaning. Such incongruity accounts for the metaphoricity of certain lexical units.

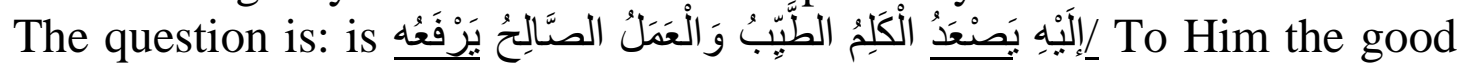
wordings mount; and the righteous deed, He raises it" metaphorical?

If, even for the sake of argument, we say that sound travels in waves and these waves settle in the upper stratosphere, even so, still it is a metaphor. The verse says that "good words" travel up to God, and good deeds "lift them up". MIPVU procedure informs us that the basic meaning of "يصعد/yaS*Cadu/go up" should be contrasted with the contextual one.

\begin{tabular}{|l|c|l|c|c|}
\hline Word & & \multicolumn{1}{c|}{ Basic meaning } & context meaning & Results \\
\hline yaS*Cadu & VVB & go up- mount -rise & the same & Non-MRW \\
\hline Alkalimu: & NN1 & $\begin{array}{l}\text { wordings } \\
\text { (abstract) }\end{array}$ & concrete entity & MRW \\
\hline Altayibu: & AJ0 & good -pleasing & the same & Non-MRW \\
\hline
\end{tabular}


The above table shows that dictionary proves there is no difference between the basic and contextual meanings of "يصعد/ yaS*Cadu /go up".

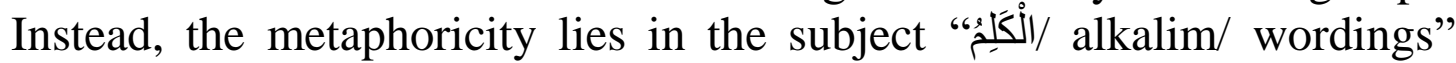
which is changed from abstract to concrete status to go with the meaning of the verb.

The second part of the verse conceptualizes "الْعَمَلُُ/aliamal/deeds" ontologically. It is personified into a human being that lifts "the good wordings". In the Arabic text, "الْعَعَلُُ/alAAamalu/ deed" is in the nominative case, which means that it is the doer of the action, unlike the translation which considers it as an object:

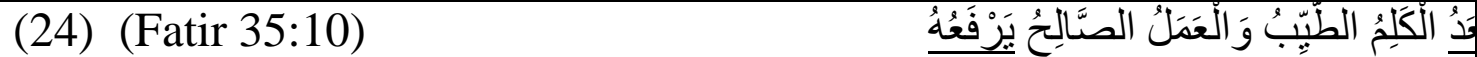

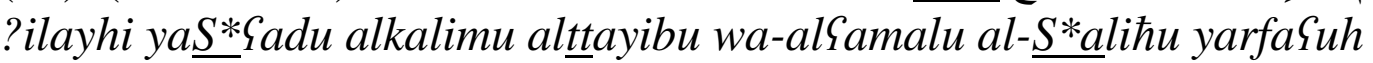

To Him the good wordings mount; and the righteous deed, He raises it. Ali

This, as simple as it sounds, may collectively be the basic argument made into a conceptual metaphor: GOOD WORDINGS ARE UP!

Concreteness is provided by mapping a sensorimotor image of moving closer onto an abstract domain in an orientational type.

\section{Limitations of the Study}

Any study based on the analysis of the Holy Qur'an will always feel meagerly inadequate, perhaps due to the intricacy of standard Arabic grammar, or the multi-level meaning the verses of the Holy Qur'an can yield. Many verses have been left out for the sake of economy.

\section{Conclusion}

The present study highlighted the use of orientational metaphors in selected verses in The Holy Qur'an. The use of orientational conceptualization is perceived in terms of the sensorimotor metaphor picturing a Muslim moving TO goodness FROM evil. This leads to the accomplishment of "piety" which is perceived via the use of the orientational metaphor PIETY IS UP, along with the good words and deeds.

The use of orientational metaphors shows the concern of the Holy Qur'an, imparted to the Muslim, to achieve peace on the social, as well as the personal, level. The integration of MIPVU in the analysis helps identify the words that are metaphorically used. Metaphorical expression intensifies meaning, clarifies the purpose and message of discourse, and makes the didactic instructions more effective. 


\section{References}

Ahrens, Kathleen. (2016). Mapping Principles for Conceptual Metaphors". In Alice Deignan, Graham Low, Zazie Todd (eds.) Researching and Applying Metaphor in the Real World. Amsterdam: John Benjamins

Al-Ghazaly, M. (2003) The Five Concepts of The Glorious Qur'an. Cairo: AlNahda Publishing Company

Ali, Abdullah Yusuf (1988). The Holy Qur'an: Text, Translation and Commentary, Elmhurst, NY: Tahrike Tarsile Qur'an, Inc.

Al-Dimishqui, I. ibn Katheer. (2007) Tafsir Al-Qur'an Al-Atheem. Dar Al-Fikr.

Al-Majmaa Alloghawi. Al-Mu'jam Al-Waseet. (2004). Cairo. Al-Shrouq AlDawlia.

Alsharif, A. (1998). Al-Majazaat Al-Nabaweyah. Cairo: Mustafa AlBaby AlHalaby.

Al-Tabari, Ja'far M. (1989). The Commentary on the Qur'an. W.F. Madelung and A. Jones (eds.). Oxford University Press

Berrada, Khalid. (2017). Metaphors of Light and Darkness in the Holy Quran:

A Conceptual Approach Metaphors of Light and Darkness in the Holy

Quran: A Conceptual Approach. $\mathrm{PhD}$

Charteris-Black, J. (2004). Corpus approaches to critical metaphor analysis. Basingstoke \& New York: Palgrave-Macmillan.

Gibbs, Raymond. (2006). Embodiment and Cognition. Cambridge: Cambridge University Press

Jabal, M. H. (2010). The Dictionary of Derivatives in the Glorious Qur'an.

Cairo. Al-Adaab Bookshop

Kaal, A. A. (2012). Metaphor in conversation. Oisterwijk: BOX Press.

Kövecses, Zoltán. (1986). Metaphors of Anger, Pride, and Love: A Lexical Approach to the Study of Concepts. Amsterdam: John Benjamins.

Kövecses, Z. (2006) Language, Mind, and Culture: A Practical Introduction.

New

York: Oxford University Press.

Kövecses, Z. (2010a). Metaphor and Culture. Acta Universitatis Sapientiae, Philologica, 2 (2), 197-220.

Lakoff, George, and Johnson, Mark. (1980). Metaphors We Live By. Chicago: The University of Chicago Press.

Lakoff, G., \& Johnson, M. (1999). Philosophy in the Flesh: The Embodied Mind and its Challenge to Western Thought. New York: Basic Books.

Pragglejaz Group. 2007. "MIP: A method for identifying metaphorically used words in discourse". Metaphor and Symbol 22(1): 1-39.

Sharaf Eldin (2014). "A Cognitive Metaphorical Analysis of Selected Verses in the Holy Qur'an ". International Journal of English Linguistics; Vol. 4, No. 6; 2014.

Soskice, J. M. (1985). Metaphor and Religious Language. Oxford: Clarendon Thabit, Mostapha. (2014). The Metaphor of Nature in the Holy Quran: A Critical Metaphor Analysis (CMA). Journal of Arabic and Human Sciences. Al-Qaseem: Burayda University 